\title{
SOUZA, Jessé. A Tolice da Inteligência Brasileira: ou como o país se deixa manipular pela elite. São Paulo: Editora Leya, 2015. 272 páginas.
}

Marco Aurélio Barbosa ${ }^{1}$

- Enviado em 13/05/2017

- Aprovado em 28/06/2017

A obra intitulada "A Tolice da Inteligência Brasileira: ou como o país se deixa manipular pela elite" do Sociólogo Jessé Souza, editada em 2015, busca ao longo de suas 272 páginas reflete sobre o imaginário construído social e historicamente sobre Brasil e seu povo como sociedade periférica e, portanto, inferior, tanto do ponto de vista cultural, social e econômico.

Buscando esquadrinhar esta construção e denunciar o seu teor ideológico, o autor realiza uma análise, grosso modo, estratigráfica do tema. Esta decomposição realizada pelo autor busca colocar em perspectiva estas noções, expondo-as como um jogo retórico, bem engendrado ao longo do processo de formação social e intelectual do Brasil contemporâneo, que tem entre vários objetivos escamotear a realidade, assim como esconder os elementos perversos de dominação existentes que permitem o domínio da sociedade por uma parcela privilegiada sobre o restante, tendo como características a naturalização deste mando, bem como, a sujeição quase fatalista das populações pobres a esta condição. Esta condição como é explicitada pelo autor e resultado de um conjunto de ideias força desenvolvidas ao longa da história intelectual do país, que se espraiam para as mais diversas áreas da vida social perpetuando este quadro crítico.

A obra divide-se em quatro capítulos, bastante densos nos quais o Souza, lançando mão de uma crítica epistêmica profunda e em certos momentos irônica, constrói sua narrativa, que busca desconstruir e colocar em evidência o apanágio ideológico, as imprecisões teóricas e o senso comum existentes por traz

\footnotetext{
${ }^{1}$ Graduado em Sociologia pela Universidade Federal do Paraná (UFPR); Licenciado em História pelas Faculdades Integradas "Espírita" (UNIBEM); Especialista em Relações Étnico-raciais pelo Núcleo de Estudos Afro-Brasileiro da Universidade Federal do Paraná (NEAB-UFPR); Mestrando em Sociologia pela Universidade Federal do Paraná (UFPR). E-mail: barbosa.marco@gmail.com
} 
de intelectuais consagrados pela intelectualidade brasileira como Raymundo Faoro, Sérgio Buarque de Holanda, Roberto DaMata, entre outros.

Para tanto, Jessé Souza parte da ideia do olhar sobre a sociedade, como algo não natural, mas antes construído, na medida em que ao questionar sobre a forma como vemos o mundo a nossa volta aponta para o fato de que este olhar é antes de mais nada resulta de algo que nos fora incutido, e que distorce o modo como vemos a realidade social, e ainda se propõe a indagar o porquê de isto ser feito, isto é, o que alguém ganharia com isto.

Neste sentido evidencia manipulação da realidade ou do olhar sobre a realidade como meio de legitimar o poder, evitando assim qualquer tipo de dissenção e/ou revolta dos grupos excluídos.

Aponta que na sociedade pré-moderna os privilégios, mesmo que injustos, eram expostos abertamente e justificavam-se por uma moral divina a qual todos estavam sujeitos, deste modo evitando qualquer tipo de questionamento mais aprofundado dos mesmos, no entanto, após o advento da construção da sociedade moderna com seu ideal de igualdade de abolição dos privilégios injustos, estes não podem mais aparecer, desta forma precisa-se criar algo que os justifique e os legitime, tornando-os em algo "merecível".

Deste modo:

É isso que faz com que o mundo social seja sistematicamente distorcido e falseado. Todos os privilégios e interesses que estão ganhando dependem do sucesso da distorção e do falseamento do mundo social para continuarem a se reproduzir indefinidamente. A reprodução de todos os privilégios injustos no tempo depende do "convencimento", e não da "violência". Melhor dizendo, essa reprodução depende de uma "violência simbólica",1 perpetrada com o consentimento mudo dos excluídos dos privilégios, e não da "violência física". É por conta disso que os privilegiados são os donos dos jornais, das editoras, das universidades, das TVs e do que se decide nos tribunais e nos partidos políticos. Apenas dominando todas essas estruturas é que se pode monopolizar os recursos naturais que deveriam ser de todos, e explorar o trabalho da imensa maioria de não privilegiados sob a forma de taxa de lucro, juro, renda da terra ou aluguel. (SOUZA, 2015, p.9-10)

No que o autor aponta a permanência de um certo imaginário ou modus operandi, que parte de um corolário de "culturalismo conservador", que se fundamenta em uma dicotomia entre povos/países avançados e povos/países atrasados do ponto de vista cultural, atribuindo aos segundos um "mal de origem" uma sina quase que inescapável que os liga ao atraso e ao subdesenvolvimento, somado a um "economicismo", isto é, uma leitura da realidade que leva em conta questões econômicas deixando ao largo outros elementos significativos das sociedades, e que formam ao ser ver os sustentáculos da 
"inteligência brasileira", que por seu grau de "resumitivo" da realidade, o que acaba por empobrecer os debates possíveis sobre o país.

Souza evidencia ainda que estes discursos não gerados espontaneamente, isto é, não são algo natural que emerge na sociedade, mas, antes são um artefato habilmente engendrado por uma intelectualidade (bem paga) para produzi-los.

Desta forma, estes são produzidos para se tornarem fatos evidentes por si mesmos, impondo-se de modo hegemônico, não pela violência, mas por uma racionalidade que se impõe como "violência simbólica", na medida em que se impõe também como um "arbitrário cultural dominante", ou seja, como cultura socialmente reconhecida.

Sendo este ideário apresentado de modo fragmentário e construído de tal forma que a visão de mundo dos agentes é sempre superficial e por isto incapaz de transcender o olhar conservador da realidade reproduzindo por conta disto, uma espécie de tapume que impede os agentes de ver além, e por sua própria natureza, acaba de fato impedindo a transformação mais profunda da sociedade, mantendo a natureza arcaica ou a sobrevivência de certo arcaísmo na sociedade e suas relações.

Desta forma, o autor aponta a crítica a estas ideias como a "primeira trincheira de luta contra os "interesses dominantes" que se perpetuam por se travestirem de supostos interesses de todos.", o que de certa forma tem a ver com a desconstrução desta falsa ideia ou ideia falseada de bem comum, e apontar o mal moral, isto é, a liderança ou lideranças negativas que se utilizam da voz coletiva para defender seus pontos de vista e manter o status quo, em jogo de sobras à que remete às ideias platônicas relativas ao mito da caverna.

Para tanto, o autor aponta durante a sua obra como a utilização das ciências e/ou de um discurso político-científico, por ele muitas vezes apontado como descuidado, preguiçoso, ideologizado e/ou enviesado, se utilizou do prestígio do discurso científico, para reificar determinadas visões de mundo, que dizem respeito ao lugar social dos sujeitos, justificar o mérito de alguns, pontando que estes debates, não se fixavam em questões centrais, neste sentido tangenciando determinadas questões, ou desviando o olhar dos sujeitos do elemento central que é a luta de classes, não só do ponto de vista das relações sociais, mas, também do ponto de vista das relações internacionais, protagonizados pelas disputas Norte/Sul, países centrais/periféricos, desenvolvidos/subdesenvolvidos,

Desta feita, ao expor estas questões denunciando este a complexidade destas questões, bem como as dimensões relativas ao conhecimento que perfazem um movimento que vai do universal ao particular e do específico ao universal, o autor denota que certos debates e mesmo certas teorias explicativas como as 
desenvolvidas pela CEPAL e estudos mais recentes desenvolvidos por Porchmann e Neri, apesar de seu mérito, acabam por reproduzir certos problemas por ele apontados, como a falta de centralidade e/ou imprecisão teórica, que ao apontar certas questões sociais, como elementos relativos ao desenvolvimento da classe média brasileira nos últimos anos, descuidaram do fato de que o conceito "classe média", não corresponde àquilo que se compreende como classe social, mas antes, faixas de renda, que por si só não se constituem como classe de fato.

Sendo assim, ao final do livro em suas considerações finais, Jessé Souza demonstra como o conjunto de prenoções, a falsa consciência de classe, as ideias falseadas sobre o que é o Brasil e o brasileiro, desembocaram na desconstrução de projetos progressistas importantes para a sociedade brasileira, bem como, a manipulação deste imaginário por parte da imprensa conservadora serviu como apêndice para amplificar e arregimentar grupos sensíveis aos interesses da classe dominante, contra o interesse geral por um lado e conformando e paralisando qualquer forma de ação contrária, seja pelo linchamento moral, seja pelo discurso de ódio, seja pela venda de uma imagem de neutralidade, que utilizando dos discursos pseudocientíficos e de velhos libelos liberais acabaram por incrementar a crise existente no país, bem como o solapamento de qualquer outro projeto de país que coloque em xeque o status quo vigente. 